\title{
MOTIVASI MEKSIKO MELAKUKAN PENETAPAN TARIF TERHADAP DISTRIBUSI PRODUK AS KE MEKSIKO DALAM HUBUNGAN PERDAGANGAN ANTARA DUA NEGARA
}

\author{
Oleh: Muhammad Fachrie (Dosen Ilmu Hubungan Internasional Universitas Jakarta) \\ Email: fachrie.muhammad@mail.ugm.ac.id
}

\begin{abstract}
This research discusses the analysis of Mexican motivation in determining tariffs on the distribution of US products to Mexico. In international law, Mexico and the US build a strong free trade cooperation in the North American Free Trade Zone (NAFTA) agreement. They agreed to implement the agreement that is built in that agreement, particularly for the exemption of tariff in the distribution of products between two countries. In fact, the US could not complete the tariff exemption agreement in the distribution of Mexican products that has been agreed in NAFTA. It delays the implementation of this agreement by complicating the distribution of goods from Mexico to the US with unilateral regulations. Eventually, this research found that Mexico motivation is to respond US regulations on its products for several years. That US action, particularly the logistics distribution cooperation, has caused Mexico experiencing difficulties in gaining profits.
\end{abstract}

Key Words: NAFTA, International Trade, Tariff

\begin{abstract}
Abstrak
Penelitian ini membahas analisis motivasi Meksiko dalam menentukan tarif distribusi produk AS ke Meksiko. Dalam hukum internasional, Meksiko dan AS membangun kerja sama perdagangan bebas yang kuat dalam perjanjian Zona Perdagangan Bebas Amerika Utara (NAFTA). Mereka sepakat untuk mengimplementasikan perjanjian yang dibangun dalam perjanjian itu, khususnya untuk pembebasan tarif dalam distribusi produk antara dua negara. Faktanya, AS tidak bisa menyelesaikan perjanjian pembebasan tarif dalam distribusi produk-produk Meksiko yang telah disepakati dalam NAFTA. Ini menunda implementasi perjanjian ini dengan mempersulit distribusi barang dari Meksiko ke AS dengan peraturan sepihak. Akhirnya, penelitian ini menemukan bahwa motivasi Meksiko adalah untuk menanggapi peraturan AS tentang produk-produknya selama beberapa tahun. Tindakan AS itu, khususnya kerja sama distribusi logistik, telah menyebabkan Meksiko mengalami kesulitan dalam mendapatkan keuntungan.

Kata Kunci: NAFTA, Perdagangan Internasional, Tarif.
\end{abstract}

\section{PENDAHULUAN}

Berdasarkan mandat dari perjanjian North American Free Trade Area (NAFTA), Amerika Serikat dan Meksiko secara bertahap diwajibkan untuk membuka batas-batas negara secara bebas dalam distribusi barang-barang dengan menggunakan truk-truk atau kendaraan angkut lainnya sesuai dengan langkah-langkah yang telah ditetapkan muali dari tahun 1995, 1997 dan 2000 
(Dicken, 2011: 412-413). Perjanjian ini memberlakukan aturan ini dimulai pada akhir 1995. Pada tahun 1997, perusahaan truk Meksiko direncanakan akan beroperasi di AS. Perusahaan truk ini diizinkan untuk menjadi operator kargo di seluruh wilayah AS pada tahun 2000. Pada tahun 2000, perusahaaan truk Meksiko dapat mengajukan permohonan untuk beroperasi di seluruh wilayah AS, akan tetapi implementasi untuk aturan ini tidak dapat dilakukan. Aturan ini ditentang pihak Amerika Serikat. Sebelum tahun 2004, penggulingan oposisi di DPR yang membela Meksiko dilakukan Mahkamah Agung Amerika Serikat. Perusahan-perusahan truk AS dan Meksiko akhirnya tidak dapat mengoperasikan aktivitas-aktivitas distribusi logistik yang melewati lintas batas negara.

Pada tahun 2009, Meksiko membalas keberlanjutan dari kegagalan AS dalam implementasi perjanjian NAFTA dengan instrumen tarif terhadap produk-produk AS (Dicken, 2011: 413). Pengingkaran kesepakatan yang telah dilakukan AS menyebabkan Meksiko mengalami kerugian, karena perusahaan truk Meksiko tidak dapat secara bebas melintasi seluruh wilayah AS. Berdasarkan faktanya, AS telah melakukan pengingkaran perjanjian NAFTA dalam hubungannya dengan Meksiko. Perjanjian NAFTA seharusnya diterima AS dan diimplementasikan ke dalam bentuk kerjasama distribusi logistik melalui perusahaan truk dua negara tersebut. AS menunda implementasi kesepakatan yang telah disepakati bahwa pada tahun 2000, perusahaan truk Meksiko yang mengangkut logistik dapat melintasi wilayah AS dalam hubungan perdagangan antara dua negara. Kasus ini adalah bentuk dari kegagalan kerjasama regional yang dilakukan negara-negara Amerika Utara melalui kerangka perjanjian NAFTA. Pembalasan yang dilakukan Meksiko ini menjadi konsekuensi logis dari apa yang telah dilakukan Amerika Serikat. Pada akhirnya, penetapan tarif yang dilakukan Meksiko dapat menjadi halangan (barrier) bagi pergerakan logistik atau distribusi logistik. Singkatnya, dinamika hubungan perdagangan antara Meksiko dan Amerika Serikat digambarkan pada Skema.1. 


\section{Skema.1: Dinamika Hubungan Perdagangan Antara Meksiko dan Amerika Serikat}

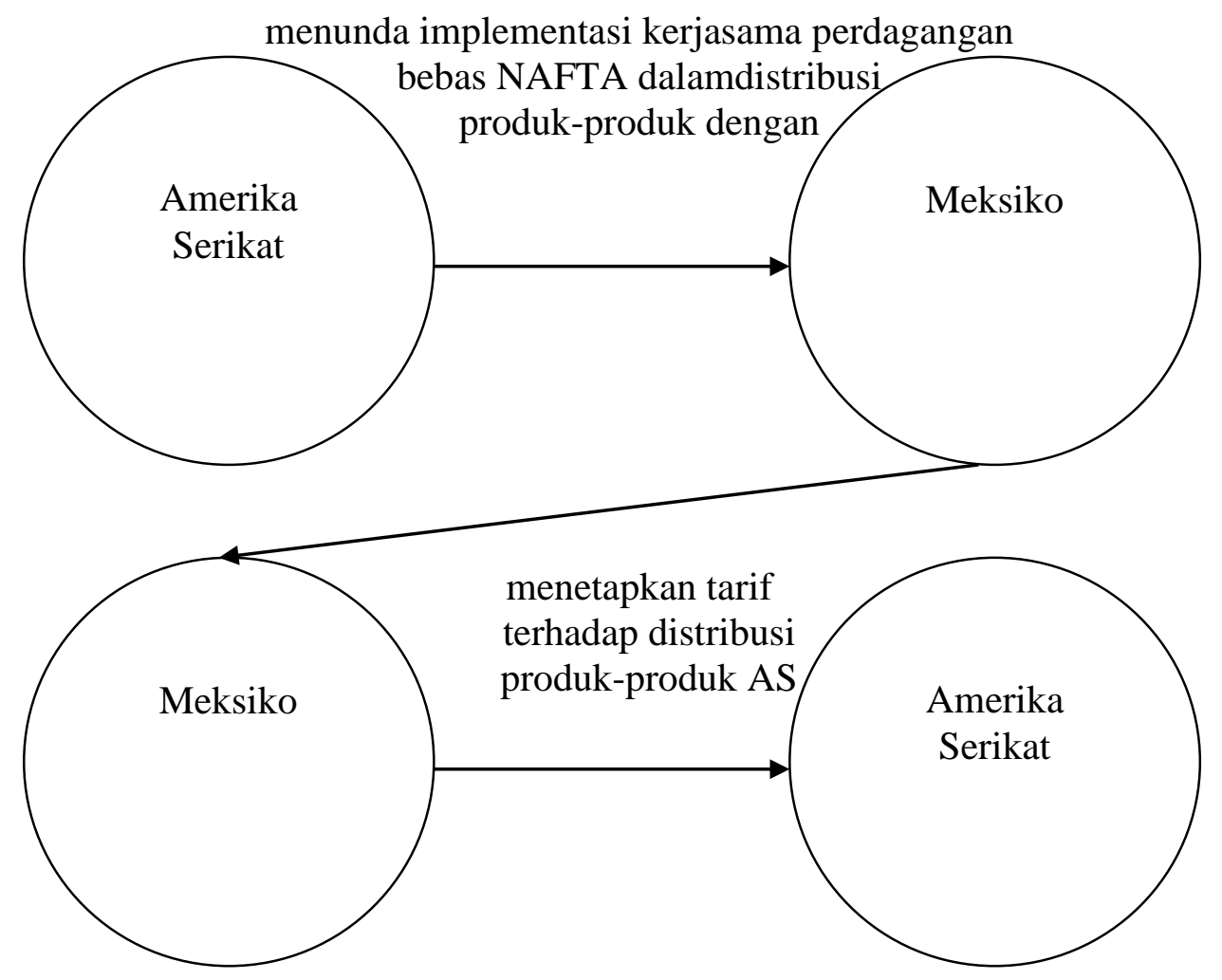

Selain itu, di dalam tulisan ini, logistik yang dibahas adalah logistik distribusi (distribution logistic), karena AS melakukan distribusi terhadap produk-produknya ke Meksiko dalam hubungan perdagangan dua negara. Logistik distribusi menjadi salah satu tipe dari logistik. Menurut Jen Kappauf, Bernd Lauterbach dan Matthias Koch, logistik dibagi menjadi tiga tipe, yaitu procurement logistics, production logistics dan distribution logistics (Kappauf, Lauterbach dan Koch, 2011: 4). Logistik distribusi memfokuskan pada proses pemesanan materi dari konsumen ke tahap pengiriman materi yang dipesan. Dalam konteks ini, AS mengalami kendala dalam proses pengiriman materi ke Meksiko, karena Meksiko menetapkan tarif terhadap impornya yang berasal dari AS. Selain itu, distribusi logistik antara Meksiko dan AS ini merujuk pada distribusi melalui jalan raya. Distribusi melalui jalan raya menjadi bagian dari non-vessel owning carriers NVOCs (Reuvid, 2004: 339). Hal ini berarti bahwa proses distribusi produk dua negara ini tidak melibatkan kapal angkut.

1. Perjanjian NAFTA

Perjanjian North American Free Trade (NAFTA) adalah sebuah perjanjian internasional yang menjadi sumber hukum dalam hubungan perdagangan antara ketiga negara pembentuknya, 
yaitu Meksiko, Amerika Serikat dan Kanada. Dalam tulisan ini, sebagai sumber hukum, NAFTA difokuskan dalam hubungan antara Meksiko dan Amerika Serikat. Sebagai sumber hukum, NAFTA tentunya mengikat dan setiap aturan-aturan yang ada harus diimplementasikan Meksiko dan Amerika Serikat. Aturan-aturan dalam perjanjian ini menjadi tolak ukur dari implementasi yang dilakukan Meksiko dan Amerika Serikat dalam hubungan perdagangan dua negara ini.

Dalam kasus ini, kesepakatan yang dicapai Meksiko dan Amerika Serikat melalui NAFTA mengikat dua negara dalam hubungan perdagangan dan pengaturan distribusi barang-barang antar dua negara. Dalam perjanjian NAFTA tahun 1992, pada bagian "Section C" mengatur tentang ukuran-ukuran non-tarif dalam perdagangan antara tiga negara, yaitu Amerika Serikat, Meksiko dan Kanada. Walaupun perjanjian ini mengatur dan mengikat dalam hubungan antara ketiga negara, perjanjian ini tentunya juga dapat menjadi landasan hukum dalam hubungan antara Meksiko dan Amerika Serikat. Berdasarkan publikasi "United States-Mexico Chamber of Commerce", perjanjian NAFTA mengatur bahwa“...the 1992 signing of the North American Free Trade Agreement (NAFTA), which required both countries to give each other's carriers full access to their roads starting in late 1995" (USMCOC, 2015). Secara hukum internasional, Meksiko dan Amerika Serikat terikat dalam perjanjian NAFTA, yang mana dua negara ini secara spesifik menyepakati pengaturan dalam perusahaan-perusahaan pengangkutan (carriers).

Dalam perjanjian NAFTA, ada aturan-aturan yang mengatur tentang logistik dan distribusi logistik antara dua negara ini. Aturan-aturan dalam perjanjian NAFTA yang mengatur tentang distribusi logistik terletak pada "article 310" tentang “Custom User Free”dan "Annex 310.1" tentang "Existing Customs User Fees" (NAFTA, 2015). Article 310 mengatur bahwa pihak-pihak yang terikat dalam perjanjian ini tidak boleh memberlakukan tarif bea cukai terhadap barangbarang dan hal ini harus merujuk pada Annex 310.1. Article 310 merujuk pada ketetapan yang dibuat dalam Annex 310.1. Dalam Annex 310.1, Meksiko dan Amerika Serikat diwajibkan untuk tidak mempersulit proses masuknya barang-barang antara dua negara melalui kantor bea cukai. Namun, perjanjian NAFTA dalam hubungan perdagangan dan distribusi logistik antara Amerika Serikat dan Meksiko menghadapi kesulitan untuk diimplementasikan. Kesulitan dalam implementasi ini berhubungan dengan kepentingan-kepentingan ekonomi dan politik antara dua negara. Conflicting interestsatau konflik kepentingan mewarnai hubungan perdagangan antara Amerika Serikat dan Meksiko dan hal ini menjadi permasalahan yang lumrah terjadi dalam hubungan antara negara-negara di dunia 


\section{Implementasi Perjanjian NAFTA}

Pada bagian ini, implementasi NAFTA dalam urusan logistrik dan distribusi antara Meksiko dan Amerika Serikat dibahas dari tahun ke tahun sejak aturan NAFTA dibentuk, yang mana pembahasan berfokus pada kerjasama operasi perusahaan truk antara dua negara dalam distribusi barang-barang. Berdasarkan publikasi dari"United States-Mexico Chamber of Commerce" atau "sebuah Kamar Dagang AS-Meksiko" yang berjudul "U.S.-Mexico Trucking Issue White Paper", ada penjelasan dari tahun ke tahun tentang distribusi barang dengan perusahaan truk antara negara Meksiko dan Amerika Serikat, dari tahun 1995 sampai dengan tahun 2009 (USMCOC, 2015). Penjelasan ini sangat berguna untuk mendapatkan gambaran tentang bagaimana trucking issue antara Meksiko dan AS menjadi permasalahan political economy dalam hubungan antara dua negara. Aturan-aturan yang dibuat dalam kesepakatan NAFTA tidak dapat sepenuhnya diimplementasikan dua negara ini, karena motif politik mewarnai dalam hubungan ekonomi antara dua negara.

Dalam hubungan antara Meksiko dan AS, ada beberapa perkembangan penting dari tahun ke tahun tentang permasalahan logistik dan distribusi. Pada tanggal 18 Desember 1995, Meksiko dan AS seharusnya menerapkan aturan tentang akses penuh bagi perusahaan truk dua negara ini dalam mendistribusikan barang-barang yang melintasi batas teritorial dua negara. Aturan ini sesuai dengan kesepakatan dalam perjanjian NAFTA yang disepakati pada tahun 1992, yang mana perjanjian ini mengatur secara umum mengatur hubungan perdagangan antara Meksiko dan AS

yang secara spesifik mengatur bagaimana distribusi barang melalui perusahaan truk melawati batas-batas dua negara. Departemen Transportasi Amerika Serikat (US Departement of Transportation/DOD), selanjutnya menetapkan dengan pengumuman bahwa pelaksanaan NAFTA dapat membahayakan keamanan nasional Amerika Serikat. Berdasarkan penilaian DOD, Pelaksanaan NAFTA ini diduga dapat mengancam keamanan melaui perusahaan pengangkut Meksiko dalam operasi-operasinya di AS. Hal ini menjadi penentangan awal yang dilakukan AS terhadap kesepakatan yang telah dicapai melalui kerangka perjanjian NAFTA.

Pada tanggal 1 Januari 2000, 6 Februari 2001, dan 18 Desember 2002, Meksiko dihadapi dengan permasalahan penundaan pengoperasian truk lintas batas, permasalahan penambahan aturan baru dan pembentukan badan-badan kelayakan transportasi. Pada tahun 2000, peningkatan pembatasan-pembatasan perlintasan truk lintas batas dilakukan. Pembatasan mencakup pada 
transportasi lintas batas kargo dari titik dan ke titik antara negara Meksiko dan AS. Permasalahan keamanan menjadi alasan bagi AS untuk menunda pelaksanaan jadwal pengoperasian truk lintas batas dua negara ini. Pada bulan ini, AS berencana untuk memenuhi kewajiban terhadap truk Meksiko seperti yang telah ditetapkan dalam perjanjian NAFTA. Selain itu, Kongres AS resmi mengeluarkan program pemeriksaan lintas batas dan mendaftarkan 22 persyaratan keamanan tambahan yang diperlukan untuk mengimplementasikan aturan-aturan yang ada. Pada tanggal 6 Februari 2001, pembentukan panel abritrase dalam hubungan antara Meksiko dan AS diusulkan Meksiko untuk menyelesaikan permasalahan yang dihadapi antara dua negara ini. Pembentukan panel ini diatur pada Bab 20 untuk mekanisme NAFTA untuk menyelesaikan perselisihan yang terjadi antara negara-negara anggota NAFTA. Pada tanggal 18 Desember 2002, selanjutnya Presiden Bush membentuk badan-badan yang bertugas untuk memantau kelayakan transportasi truk komersial Meksiko. Aturan ini berdasarkan pada penandatangan "the Transportation and Related Agencies Appropriation Act”, yang dilakukan Presiden Bush. Dalam kesepakatan tersebut, Departement of Transportation (DOT) bertanggung jawab dalam memberikan bantuan pendidikan dan memberikan penjelasan teknis untuk operator Meksiko dan kemudian badan ini melakukan peningkatan pembatasan penyeberangan truk lintas batas antara dua negara. Hal ini berlandaskan aturan hukum, yaitu Pasal 350 dalam "the Transportation and Related Agencies Appropriation Act".

Pada tahun 2003 sampai dengan tahun 2006, negosiasi tentang persyaratan dalam Pasal 350 dilakukan Meksiko dan AS, yang mana "Pre-Safty Authority Audit (PASAs)"dari perusahaan angkutan Meksiko termasuk dalam pembahasan negosiasi tersebut. Selain itu, pada bulan Juni tahun 2004, Mahkamah Agung AS menetapkan bahwa studi lingkungan tidak diperlukan dalam aturan dalam pelaksanaannya dan memberikan mandat kepada DOT untuk tetap menegakkan aturan hukum dan standar federal AS. Namun, pada taanggal 13 Februari tahun 2007, Meksiko dan AS mencapai kesepakatan untuk menginspeksi operator dari perusahaan truk dan PASAs. Hal ini berlanjut pada program percontohan lintas batas yang melebihi 20 sampai dengan 25 Mil zona komersil, dengan melibatkan proyeksi 100 perusahaan truk Meksiko dan yang beroperasi sejumlah 500 truk.

Selanjutnya, pada tahun 2008, AS berpengaruh dalam pengaturan tentang pembentukan Panel Evaluasi Independen, untuk proyek demontrasi lintas batas dengan Meksiko. Hal ini disampaikan Sekretaris DOT, yaitu Peters. Panel bertugas dalam menyiapkan laporan untuk 
memperpanjang program percontohan berdasarkan permintaan DOT. Perpanjangan program diperpanjang jika program ini dinilai menguntungkan. Namun, pada tahun 2009, Meksiko membalas apa yang telah dilakukan AS dengan penggunaan instrumen tarif terhadap produk AS (Dicken, 2011: 413). Meksiko menggunakan tarif terhadap produk AS, karena kegagalan AS dalam mengimplementasikan perjanjian NAFTA. Berdasarkan uraian diatas tentang perkembangan perjanjian NAFTA dari tahun ke tahun, AS melakukan pembatasan-pembatasan yang ketat dan melakukan penghentian operasi perusahaan truk lintas batas yang membawa produk asal Meksiko.

Pada tahun 2009, perselihan angkutan logistik antara Meksiko dan AS mencapai titik puncak. Robert J. Carbaugh (2011: 3-6) dalam tulisannya yang berjudul, "NAFTA and the U.S.Mexican Trucking Dispute”, menjelaskan bahwa, The cross-border trucking disputereached a climax in 2009, when Mexico imposed retaliatory tariffs on U.S. imports. Pada bulan Agustus tahun 2010, pemerintah Meksiko melakukan pembalasan lain dengan cara meningkatkan tarif impor dari produk-produk AS, sehingga hal ini tentunya merugikan AS. Peningkatan tarif ini menjadi bagian dari tekanan politik Meksiko terhadap AS. Ada beberapa produk yang ditambahkan dalam daftar produk-produk yang dinaikkan tarif bea masuk impornya. Meksiko menaikkan tarif sebanyak 26 produk-produk ke Meksiko dan menghapus daftar 16 produk-produk AS dari total 89 produk. Meksiko membawa sebanyak 99 produk baru dari 43 negara dengan besar nilai ekspor, yaitu 2,6 Juta Dolar. Selain itu, Meksiko hanya melakukan pembalasan tarif terhadap AS dengan jarak 5 sampai dengan 25 persen dari tarif asli. Disamping itu, Meksiko dan AS pada bulan Maret 2011 melakukan upaya untuk menyelesaikan persengketaan antara dua negara. Namun, merujuk pada sejarahnya, kesepakatan ini berpeluang untuk sulit diimplementasikan sebagaimana yang terjadi pada tahun-tahun sebelumnya.

\section{Konflik Kepentingan Antara Meksiko dan Amerika Serikat}

Walaupun NAFTA dibentuk berdasarkan kesepakatan bersama, kesepakatan ini tidak dapat dinilai sebagai sebuah kewajiban bagi setiap negara yang terlibat untuk mengikuti dan mematuhi aturan-aturan yang dibuat. Negara-negara yang tergabung dalam perjanjian NAFTA dapat menolak kesepakatan-kesepakatan di dalam perjanjian ini dengan alasan-alasan bahwa perjanjian ini perlu disesuaikan atau ditambah dengan aturan-aturan baru. Dalam hubungan perdagangan dengan Meksiko, kepentingan Amerika Serikat melakukan pembatasan persyaratan 
dalam operasional truk-truk Meksiko adalah untuk menjamin keamanan AS. Dalam publikasi resmi "United State-Mexico Chamber of Commerce", permasalahan keamanan yang dihadapi AS adalah "...the safety of Mexican trucks; the terrorist attacks of September 11, 2001; arguments about human trafficking and illegal immigration; and assertions related to longstanding efforts to curtail smuggling of narcotics and weapons across the U.S.-Mexican border" (USMCOC, 2015). Kutipan ini menerangkan beberapa alasan dari AS untuk menunda implementasi NAFTA, yaitu terorisme, perdagangan manusia dan migrasi ilegal, penyeludupan narkotika dan senjata. Hal ini membuktikan bahwa ekonomi dapat dipengaruhi permasalahan politik dan keamanan.

Selain AS, Meksiko juga memiliki kepentingan dalam hubungan perdagangan, khususnya distribusi barang-barang asal Meksiko ke AS. Penundaan pelaksanaan mekanisme perdagangan yang disepakati dalam NAFTA menyebabkan Meksiko sulit untuk mendapatkan keuntungan dalam hubungan antara dua negara. Pemberlakuan persyaratan kelayakan operasi truk-truk yang dikelola perusahaan truk Meksiko menyulitkan negara ini dalam memenuhi persyaratan yang ada, sehingga implementasi operasi truk melintasi batas-batas teritorial dua negara sulit untuk diwujudkan, karena negara-negara yang terlibat tidak mendapatkan kondisi yang saling menguntungkan atau win win solution dalam kerjasama NAFTA. Dalam hubungan perdagangan antara dua negara, "Mexico is the United States' third largest trading partner, after Canada and China, while the United States is Mexico's largest trading partner" (Carbaugh, 2011: 1-10). Hal ini berarti bahwa AS menjadi mitra dagang yang besar bagi Meksiko, sehingga pembatasan dengan persyaratan dalam operasi perusahaan truk Meksiko ke wilayah AS dan penetapan tarif bea masuk yang tinggi, merugikan kepentingan nasional Meksiko dalam bidang ekonomi.

4. Penetapan Tarif Distribusi Produk-Produk AS ke Meksiko

Meksiko mengeluarkan kebijakan balasan dalam merespon penundaan implementasi yang dilakukan AS dalam kerjasama NAFTA. Kebijakan balasan yang dilakukan Meksiko berupa penetapan tarif terhadap impor dalam hubungan dagangnya dengan AS. Kebijakan ini tentunya secara politik bertujuan untuk menekan AS untuk memenuhi kesepakatan yang telah dicapai bersama dalam kerjasama NAFTA. Penetapan tarif impor Meksiko ini tentunya merugikan ekonomi AS, karena terjadi penurunan ekspor AS ke Meksiko. Sebagai balasan terhadap penetapan aturan-aturan tentang distribusi produk dengan truk yang dilakukan AS melalui NAFTA, Pemerintah Meksiko melakukan non-compliance dengan melakukan penetapan tarif untuk produk-produk pertanian dan non-pertanian asal AS dari bulan Maret tahun 2009 sampai 
dengan bulan Oktober tahun 2011 (Zahniser, Hertz dan Argoti, 2015: 1). Kebijakan Meksiko ini tidak hanya bertujuan untuk memengaruhi ekonomi AS, akan tetapi kebijakan ini juga bertujuan untuk memengaruhihubungan politik antara dua negara.

Perselisihan tentang operasional perusahaan truk antar dua negara membawa pada penetapan tarif terhadap produk ekspor pertanian AS ke Meksiko. Ekspor pertanian AS selama bulan Maret tahun 2009 sampai dengan bulan Oktober tahun 2011 mengalami penurunan, yaitu 22 persen atau setara dengan 984 Juta Dolar dan sekitar 26 dari 50 produk ekspor pertanian AS ke Meksiko terpengaruh pembalasan tarif tersebut. Hal ini berarti bahwa AS mengalami kerugian dalam hubungan perdagangannya dengan Meksiko. Disamping kerugian secara politik, penurunan ekspor AS ke Meksiko adalah kurugian yang dialami AS dalam bidang ekonomi.

\section{PEMBAHASAN}

Dalam menganalisis tentang motivasi Meksiko dalam melakukan penetapan tarif distribusi terhadap distribusi produk AS ke Meksiko, perspektif Merkantilisme dapat digunakan sebagai instrumen analisis. Berbeda dengan perspektif Liberalisme dalam memandang ekonomi, perspektif Merkantilisme lebih menekankan pada peranan negara sebagai aktor dominan dalam ekonomi politik internasional. Menurut perspektif Merkantilisme, negara tidak dapat dipisahkan dalam permasalahan ekonomi, sehingga negara juga harus terlibat dalam pengambilan kebijakan ekonomi.

Merkantilisme memandang bahwa negara menjadi aktor penting di dalam memengaruhi ekonomi. Lisa L. Martin di dalam buku yang berjudul Oxford Handbook of Political Economy of International Trade mengutip pendapat Thomas Hobbes (dalam Lisa L. Martin, 2015: 2) dalam menjelaskan Merkantilisme, yaitu “Wealth is Power and Power is Wealth". Berdasarkan pendapat Hobbes tersebut, Lisa L. Martin (2015: 2) memandang bahwa kekuatan militer dan kekuatan ekonomi adalah dua sisi yang berbeda dari satu koin yang sama. Hal ini berarti bahwa suatu negara harus memiliki power kekuatan dalam memperjuangkan kepentingan ekonominya. Pemerintah mengatur dan mengintervensi jaringan perdagangan dan melakukan manipulasi perdagangan (rasio biaya impor ke ekspor) untuk memperkaya mereka sendiri dan pendukung domestik mereka. Merkantilisme dapat memandang penetapan tarif distribusi yang dilakukan Meksiko terhadap produk-produk Amerika Serikat, karena Meksiko menggunakan kekuatan atau power dari pemerintahnya dalam menetapkan regulasi tarif masuk barang impor dari produk-produk AS. 
Dalam konteks ini, otoritas domestik Meksiko berkuasa penuh dalam menetapkan regulasi perdagangannya dengan Amerika Serikat untuk menghindari kerugian-kerugian yang ada.

Mochtar Mas'oed (1990: 27) dalam bukunya yang berjudul Ekonomi Politik Internasional, menjelaskan bahwa ada dua asumsi dasar dalam memahami perspektif Merkantilisme dalam ilmu hubungan internasional. Pertama, negara menjadi aktor dominan dalam ekonomi politik internasional dan juga menjadi unit analisis sejati. Dalam sistem internasional yang anarkis, Merkantilisme memandang bahwa kedaulatan, penentuan dan justifikasi prilaku sendiri dan pengabaian terhadap wewenang adalah hak-hak bagi setiap negara. Kedua, maksimalisasi kekuasaan adalah hal yang selalu diusahakan dan dilakukan negara bangsa. Hal ini dilakukan untuk mengantisipasi penggunaan kekerasan atau daya paksa negara lain. Singkatnya, Merkantilisme berusaha untuk melibatkan negara dalam setiap pengambilan kebijakan ekonomi untuk mengantisipasi ancaman yang mungkin saja muncul jika keterlibatan negara diminimalkan. Hal ini menyebabkan Merkantilisme berbeda dengan Liberalisme yang menginginkan negara untuk tidak ikut campur dalam permasalahan ekonomi.

Berdasarkan asumsi-asumsi Merkantilisme, kebijakan pembalasan tarif yang dilakukan Meksiko terhadap barang-barang produksi AS adalah sesuatu kebijakan politik Meksiko untuk merespon monopoli yang dilakukan AS dalam kerangka kerjasama NAFTA. Dari tahun 1995 sampai dengan tahun 2008, AS berusaha untuk menghindari hubungan perdagangan dengan Meksiko dalam operasi distribusi barang melalui perusahaan truk dua negara ini. Dalam konteks ini, AS menetapkan aturan-aturan distribusi barang-barang melalui perusahaan truk Meksiko ke AS dengan persyaratan-persyaratan yang ketat. Persyaratan-persyaratan operasi truk Meksiko ke wilayah AS diatur dengan ketat melalui mekanisme yang telah ditetapkan sepihak Departement of Transportation (DOT) AS. Walaupun ada United States-Mexico Chamber of Commerce dalam hubungan dua negara, kamar dagang ini tidak dapat secara efektif menyelesaikan perselisihan yang terjadi antara dua negara. Selain alasan pemberlakukan aturan-aturan yang ketat, Meksiko memberlakukan kebijakan pembalasan tarif terhadap barang-barang produksi AS, karena kebijakan ekonomi AS yang menunda pelaksanaan atau implementasi perjanjian NAFTA. Penundaan implementasi kerjasama NAFTA tentunya merugikan Meksiko secara ekonomi dan hal ini memaksa Meksiko untuk menggunakan kebijakan politik dalam menyelesaikan permasalahan ekonomi yang ada. 
Dalam permasalahan logistik dan distribusi, argumen-argumen yang dijelaskan Peter Dicken dalam bukunya yang berjudul "Global Shift Mapping the Changing Contour of the World Economy", sangat relevan dalam hubungannya dengan perspektif Merkantilisme. Peter Dicken (2011: 401) menjelaskan bahwa pada dasarnya tidak ada kendala politik dan kendala lainnya yang berperan dalam menyulitkan sistem dasar logistik dan distribusi, akan tetapi di dalam prakteknya struktur dan operasi logistik dan proses distribusi dipengaruhi fenomena politik. Dalam hal ini, Dicken (2011: 401) menjelaskan bahwa ada dua hal yang secara signifikan dapat menghalangi pergerakan (movement). Pertama, transfer barang dari satu lokasi ke lokasi lain dengan moda transportasi yang berbeda secara signifikan dapat menghadalangi pergerakan (movement). Kedua, komplikasi bea cukai, tarif, tugas, administrasi dan sejenisnya menjadi batasan-batasan politik yang menghalangi pergerakan (movement). Kegiatan ekonomi global menyebabkan hambatan tersebut menjadi semakin penting. Hal ini menyebabkan ada banyak tahapan dalam proses distribusi produk. Dalam pengiriman barang pada skala internasional melibatkan interaksi pemangku kepentingan yang berbeda dengan total jumlah sekitar 25 orang, menghasilkan dokumen sebanyak 30 sampai dengan 40, menggunakan 2 sampai 3 moda transportasi (transportasi udara, darat dan laut) dan melibatkan sekitar 12 sampai 15 lokasi fisik yang berbeda.

Berdasarkan argumen-argumen yang dijelaskan di atas, penetapan tarif terhadap distribusi produk AS ke Meksiko yang dilakukan Meksiko adalah bentuk dari praktek struktur, operasi logistik dan proses distribusi yang dipengaruhi fenomena politik. Dalam kasus ini, fenomena politik merujuk pada apa yang telah dilakukan AS terhadap Meksiko pasca-kerjasama NAFTA. Hal ini menyebabkan Meksiko mendapatkan kesulitan dalam mengekspor dan mendistribusikan barang-barang produksi domestik ke AS. Meksiko membalas AS dengan menetapkan regulasi tarif terhadap distribusi produk AS ke Meksiko. Penetapan tarif balasan Meksiko ini adalah konsekuensi logis dari penundaan implementasi kerangka kerjasama distribusi logistik di dalam perjanjian NAFTA yang dilakukan AS.

Penetapan tarif yang dilakukan Meksiko menjadi bagian dari komplikasi yang dapat menghalangi pergerakan (movement) dari barang-barang dalam proses distribusi produk. Hal ini menjadi hambatan bagi dua negara dalam melakukan hubungan perdagangan, terutama dalam permasalahan distribusi produk. Robert J. Carbaugh (2011: 1-10), dalam tulisannya yang berjudul "NAFTA and the U.S-Mexican Trucking Dispute", menjelaskan bahwa ekspor kentang AS ke Meksiko mengalami penurunan sejak penetapan tarif yang diberlakukan Meksiko terhadap 
produk-produk AS. Penetapan tarif yang diberlakukan Meksiko untuk produk-produk pertanian dan non-pertanian asal AS dari bulan Maret tahun 2009 sampai dengan bulan Oktober tahun 2011memengaruhi 26 dari 50 produk ekspor pertanian AS ke Meksiko dengan persentase penurunan sekitar 22 persen atau setara dengan 984 Juta Dolar (Zahniser, Hertz dan Argoti, 2015: 1). Meksiko membawa 99 produk baru dari 43 negara dengan besar nilai ekspor, yaitu 2,6 Juta Dolar. Meksiko melakukan pembalasan tarif terhadap AS dengan jarak 5 sampai dengan 25 persen dari tarif asli. Di samping itu, pada bulan Maret 2011, Meksiko dan AS berupaya untuk menyelesaikan persengketaan antara dua negara, namun kesepakatan menjadi sulit untuk dicapai berdasarkan sejarah dua negara ini yang terjadi tahun-tahun sebelumnya. Hal ini berarti bahwa AS mengalami kerugian dalam hubungan perdagangannya dengan Meksiko. Disamping kerugian secara politik, penurunan ekspor AS ke Meksiko adalah kurugian yang dialami AS dalam bidang ekonomi. Dalam konteks ini, penetapan tarif yang dilakukan Meksiko mengurangi pergerakan (movement) dari produk-produk AS ke Meksiko. AS menghadapi rintangan (barrier) dalam mendistribusikan produk-produknya, karena Meksiko menerapkan tarif yang ketat terhadap produk-produknya.

Pada prinsipnya, Economic Union (EU) atau Persatuan Ekonomi mengurangi tarif, namun dalam prakteknya negara memiliki peranan penting dalam mengatur ekonominya, termasuk permasalahan tarif. Persatuan Ekonomi, seperti Uni Eropa, ASEAN, NAFTA, dan lain-lain, menghasilkan deregulasi atau deregulation yang berdampak khusus pada strategi-strategi logistik pada perusahaan-perusahaan dalam melakukan hubungan perdagangan internasional. Dalam contoh kasus Uni Eropa, pengurangan dari hambatan tarif menjadi salah satu contoh dari keuntungan yang disebabkan Persatuan Ekonomi (Rushton, Croucer dan Baker, 2010: 63). Kerjasama EU memberikan keuntungan bagi negara-negara anggotanya dalam melakukan perdagangan internasional. Dalam kasus distribusi produk dagang AS ke Meksiko, NAFTA tidak berhasil dalam mengatur berhasil sepenuhnya dalam mengatur distribusi produk-produk antara dua negara. Meksiko memberlakukan hambatan tarif terhadap distribusi produk AS. Hal ini tentunya menjadi penghalang atau atau penghambat, padahal keterikatan dua negara ini di dalam kerjasama NAFTA seharusnya memudahkan hubungan distribusi perdagangan.. Walaupun secara konsep Persatuan Ekonomi memberikan keuntungan, seperti deregulasi, negara bisa saja menolak konsep yang ada dan melakukan manuver politik dalam memperjuangkan kepentingan nasionalnya. 
Dengan demikian, penetapan tarif yang dilakukan Meksiko terhadap produk AS adalah kebijakan yang berhubungan dengan ekonomi politik. Penetapan tarif yang dilakukan Meksiko terhadap produk-produk AS menyebabkan hambatan (barrier) bagi AS dalam meningkatkan ekspor produk-produknya ke Meksiko. Hambatan berada pada kesulitan AS dalam mendistribusikan barang-barangnya dengan biaya yang murah ke Meksiko. Kebijakan AS yang menyulitkan Meksiko di dalam kerangka kerjasama NAFTA menyebabkan AS menghadapi kebijakan balasan yang dilakukan Meksiko. Meksiko berusaha untuk menekan AS secara politik, karena AS lebih cenderung ingin terus menunda implementasi kesepakatan yang telah dicapai dalam kerangka perjanjian NAFTA dengan berbagai upaya, seperti persyaratan operasional perusahaan truk Meksiko. Berikut ini analisis tentang motivasi Meksiko dalam melakukan penetapan tarif terhadap distribusi produk AS ke Meksiko digambarkan pada Skema. 2

Skema.2: Motivasi Meksiko dalam Melakukan Penetapan Tarif terhadap Distribusi Produk AS ke Meksiko.

Penyebab-penyebab:

1. AS menunda implementasi kerjasama NAFTA, khususnya permasalahan distribusi logistik dengan Meksiko

2. Hambatan regulasi prosedural trucking dalamdistribusi produk Meksiko ke AS

3. Dominasi AS dalam hubungan perdagangan, terutama dominasi dalam pengaturan distribusi logistik.

Penurunan ekspor produk pertanian dan non-pertanian sekitar 22 Persen atau 984 Juta Dolar AS.

Dari bulan Maret 2009 sampai dengan Oktober 2011, sekiatar 26 dari 50 produk ekspor pertanian dan non-pertanian AS mengalami penurunan

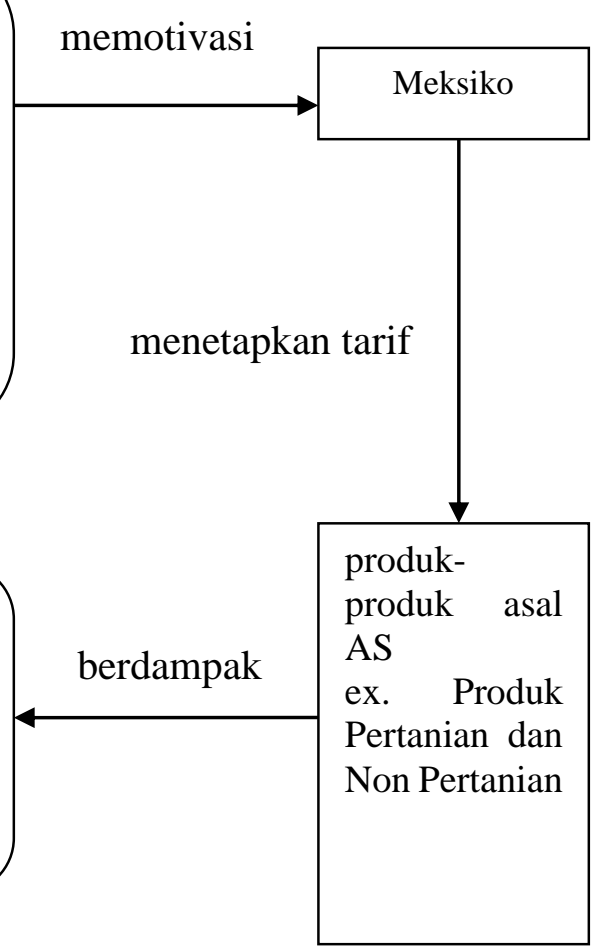




\section{KESIMPULAN}

Penetapan tarif impor yang dilakukan Meksiko terhadap distribusi produk-produk AS ke Meksiko memiliki motif politik di dalamnya. Penetapan tarif ini bertujuan untuk membalas penundaan implementasi kerjasama NAFTA yang dilakukan AS, khususnya permasalahan distribusi logistik antara dua negara. Dalam hubungan perdagangan dengan AS, Meksiko menghadapi prosedur trucking yang ketat dalam mendistribusikan produknya ke AS, padahal kerjasama NAFTA seharusnya mempermudah hubungan antara dua negara. Meksiko harus comply terhadap regulasi distribusi logistik yang telah ditetapkan Departement of Transportation (DOT) AS secara sepihak. Dalam hubungan distribusi produk-produk perdagangan dengan Meksiko, AS sangat mendominasi dalam menetapkan regulasi dan tidak merujuk pada kesepakatan-kesepakatan di dalam perjanjian NAFTA, terutama dominasi dalam pengaturan distribusi logistik. Hal ini semua menjadi penyebab-penyebab mengapa Meksiko menetapkan tarif terhadap distribusi produk-produk AS ke Meksiko. Sebagai dampak dari penetapan tarif terhadap produk AS yang dilakukan Meksiko, ekspor produk pertanian dan non-pertanian AS ke Meksiko mengalami penurunan dan hal ini tentunya merugikan AS. Singkatnya, penetapan tarif yang dilakukan Meksiko ini adalah upaya untuk membalas apa yang dilakukan AS terhadap Meksiko selama beberapa tahun. Penolakan AS dalam mengimplementasikan perjanjian NAFTA, khususnya kerjasama distribusi logistik menyebabkan Meksiko mengalami kesulitan dalam mendapatkan keuntungan dalam hubungan perdagangan antara dua negara ini.

\section{DAFTAR PUSTAKA}

\section{Buku}

Dicken, Peter, 2011. Global Shift Mapping the Changing Contour of the World EconomySixth Edition. New York: Guilford Press.

Kappauf, Jen, Lauterbach, Bernd, dan Koch, Matthias , 2011. Logistic Core Operations with SAP, Procurement, Production and Distribution Logistics. New York: Springer.

Martin,Lisa L., ed,2015. Oxford Handbook of Political Economy of International Trade. New York: Oxford University Press.

Mas'oed, Mohtar, 1990. Ekonomi Politik Internasional. Yogyakarta: Pusat antar universitas Gajah Mada. 
Reuvid, Jonathan, 2004. A Handbook of World Trade Second Edition. London and Sterling: GMB Publishing Ltd.

Rushton, Alan, Croucer, Phil, dan Baker, Peter, ed,2010. Handbook of Logistics and Distribution Management Fourth Edition. London: Kogan Page Limited.

\section{Jurnal}

Carbaugh, Robert J., 2011, NAFTA and the U.S.-Mexican Trucking Dispute. Journal of International and Global Economic Studies, 4 (1). Hal. 1-10.

Zahniser, Steven, Hertz, Tom, dan Argoti, Monica, 2015,Quantifying the Effects of Mexico's RetaliatoryTariffs on Selected U.S. Agricultural Exports. Applied Economic Perspectives and Policy, Vol.0, No. 0. Hal.1-20.

\section{Perjanjian Internasional}

North American Free Trade Area Agreement (NAFTA). (Bab 3), : Amerika Serikat, Kanada dan Meksiko.

\section{Publikasi Resmi}

United States-Mexico Chamber Of Commerce, U.S Mexico Trucking Issue White Paper, <http://www.usmcoc.org/papers-current/4-Trucking-Issue-White-Paper.pdf>, [diakses 20 April 2015]. 